\title{
PRODUK PEMBIAYAAN WISATA RELIGI HAJI PADA KOPERASI DALAM PERSPEKTIF HUKUM POSITIF DAN HUKUM EKONOMI SYARIAH
}

\author{
Achmad Otong Busthomi, Wasman dan Nurul Farichah \\ Fakultas Syariah dan Ekonomi Islam \\ Institut Agama Islam Negeri Syekh Nurjati Cirebon \\ email: tomibust@yahoo.com, wasman1959@yahoo.co.id dan nurulfarichah36@gmail.com
}

\begin{abstract}
The large number interest of community in performing the hajj became one of the reference for Koperasi Nusantara in innovating the financing product. This product can be used for members of Koperasi Nusantara with some terms and conditions that have been determined. In financing, Koperasi Nusantara usesmurabaha financing. On the other side there should be a guarantee given to this community that there is portion number of Hajj and SPPH.This case study uses qualitative research method with descriptive approach that aims to get accurate data about financing in hajj. Techniques of collecting data used in this study are observation, interview and documentation. The collected data is analyzed by using qualitative analysis method which is done logically and systematically. Koperasi Nusantara as a savings and loan cooperative (KSP) that presents the product of religious tourism hajj financing enough to attract the attention of the public. In practice, however, this financing is in contrast to (PMA) no. 24 of 2016 on Amendment to Regulation of the Minister of Religious Affairs no. 30 Year 2013 concerning Banks Receiving Deposit Fees for Hajj Implementation that financing with the type of bailout had been prohibited.
\end{abstract}

Keywords: Financing, Hajj, Mechanism, Murabahah and Policy.

\begin{abstract}
Abstrak
Besarnya minat masyarakat dalam menunaikan ibadah haji menjadi salah satu acuan bagi Koperasi Nusantara dalam menginovasikan produk pembiayaan. Di dalam pembiayaan ini Koperasi Nusantara menggunakan pembiayaan murabahah. Bukan hanya itu, dalam pembiayaan ini juga harus ada jaminan yang diberikan kepada pihak koperasi yaitu berupa nomor porsi haji dan SPPH. Jenis penelitian ini adalah case study (studi kasus). Teknik pengumpulan data yang dilakukan adalah obeservasi, wawancara dan dokumentasi. Datadata yang terkumpul kemudian dianalisis dengan menggunakan metode analisis kualitatif normatif yang dilakukan secara logis dan sistematis. Koperasi Nusantara sebagai koperasi simpan pinjam (KSP) yang menghadirkan produk pembiayaan wisata religi haji cukup menarik perhatian masyarakat luas. Namun dalam prakteknya pembiayaan ini bertolak belakang dengan (PMA) No. 24 Tahun 2016 tentang Perubahan Atas Peraturan Menteri Agama No. 30 Tahun 2013 tentang Bank Penerima Setoran Biaya Penyelenggaraan Ibadah Haji bahwa pembiayaan dengan jenis talangan haji telah dilarang.
\end{abstract}

Kata Kunci: Pembiayaan Wisata Religi Haji, Mekanisme, Murabahah dan Kebijakan. 


\section{PENDAHULUAN}

Cirebon merupakan salah satu kota yang berada di wilayah Jawa Barat. Cirebon sering dikenal dengan Kota Wali/Kota Udang. Jumlah penduduk kota Cirebon berdasarkan database kependudukan dan pencatatan sipil, saat ini telahmencapai 388.854 jiwa. Melihat banyaknya penduduk, tidak menutup kemungkinan bahwa minat masyarakat kota cirebon untuk menunaikan ibadah haji pun meningkat.

Ibadah haji merupakan salah satu rukun Islam yang kelima dan mempunyai karakteristik yang khusus, berbeda dengan rukun Islam lainnya, karena apabila dilihat dari satu sisi, haji merupakan ibadah mahdah berupa kewajiban yang dilaksanakan secara individual, tetapi dalam pelaksanaannya di Indonesia harus dilaksanakan secara kolektif sesuai dengan peraturan perundang-undangan yang berlaku. Dengan demikian praktek ibadah haji tidak hanya terikat oleh aturan-aturan fikih saja, tetapi juga terikat oleh peraturan perundang-undangan yang mengatur perjalanannya. Besarnya nilai setoran awal untuk memperoleh nomor porsi haji membuat masyarakat muslim kebingungan. Terlebih lagi keinginan untuk menunaikan ibadah haji bukan saja untuk masyarakat kelas atas, namun masyarakat dengan pendapatan ekonomi pas-pasan juga ingin menyempurnakan rukun Islam dengan ikut menunaikan ibadah Haji seperti halnya masyarakat ekonomi menengah ke atas.

Penyelenggaraan Ibadah Haji merupakan tugas nasional dan menyangkut martabat serta nama baik bangsa, kegiatan penyelenggaraan ibadah haji menjadi tanggung jawab Pemerintah. Namun, partisipasi masyarakat merupakan bagian yang tidak terpisahkan dari sistem manajemen penyelenggaraan Ibadah Haji. Persoalan mendasar yaitu masalah pendanaan, dimana untuk mendapatkan porsi haji calon jamaah harus membayar Biaya Perjalanan Ibadah Haji (BPIH). Banyak para calon jamaah haji yang ingin melaksanakan ibadah haji namun biaya yang tersedia tidak mencukupi untuk pembayaran BPIH. ${ }^{1}$ Di Indonesia untuk memperoleh nomor porsi haji para calon jamaah haji minimal harus sudah menyetor awal Biaya Penyelenggara Ibadah Haji (BPIH) sebesar Rp 25.000.000,- melaluiBank Penerima Setoran Biaya Penyelenggaraan Ibadah Haji (BPS-BPIH) yang ditunjuk oleh Menteri Agama untuk menerima setoran BPIH untuk bisa mendapatkan nomor porsi haji. ${ }^{2}$

Di samping LKS, terdapat pula Koperasi yang menawarkan talangan dalam produk simpan pinjam. Secara umum ruang lingkup kegiatan usaha koperasi simpan pinjam adalah penghimpunan dan penyaluran dana yang berbentuk penyaluran pinjaman terutama dari dan untuk anggota. Namun dalam pengemasannya produk dana talangan haji yang ditawarkan oleh koperasi ini berbentuk pembiayaan.

Koperasi sebagai sebuah lembaga ekonomi rakyat telah lama dikenal di Indonesia, bahkan Mohammad Hatta salah seorang proklamator Republik Indonesia yang dikenal sebagai bapak koperasi, mengatakan bahwa koperasi adalah badan usaha bersama bergerak di bidang perekonomian, beranggotakan mereka yang umumnya berekonomi yang lemah yang bergabung secara sukarela dan atas dasar persamaan hak dan kewajiban melakukan usaha yang bertujuan untuk mememuhi kebutuhan-kebutuhan para anggotanya. ${ }^{3}$

Koperasi Nusantara merupakan sebuah koperasi yang berkerjsama dengan PT POS Indonesia (Persero) yang berperan aktif membantu pemerintah dalam program

${ }^{1}$ Tommy Jorghi Pahlevi, "Tinjauan Yuridis terhadap Penggunaan Dana Talangan Haji Menurut Hukum Islam Dikaitkan dengan Undang-Undang Nomor 34 Tahun 2009 tentang Penyelenggaraan Haji dan Undang-Undang Nomor 21 Tahun 2008 tentang Perbankan Syariah", Skripsi (Bandung: Universitas Pasundan Bandung, 2011), 2.

${ }^{2}$ Muhammad Bahtiyar Rifai, "Tinjauan Hukum Islam terhadap Produk Dana Talangan Haji”, Skripsi (Yogyakarta: UIN Sunan Kalijaga, 2010), 2.

${ }^{3}$ Fitri Nurhayati dan Ika Saniyati Rahmaniyah, Koperasi Syariah (Surakarta: PT Era Intermedia, 2008), 12. 
mensejahterakan masyarakat menengah ke bawah dan meningkatkan perekonomian kerakyatan. Dari kerjasama ini melahirkan produk simpan pinjam dan salah satunya adalah produk pembiayaan wisata religi haji atau dengan kata lain pembiyaan yang berjenis seperti dana talangan haji. Pada perkembanganya memang koperasi simpan pinjam ini melayani anggota dan calon anggota Koperasi Nusantara. Calon anggota koperasi ini nantinya haruslah terlebih dahulu terdaftar dalam keanggotaan Koperasi Nusantara dengan memenuhi persyaratan yang sudah ditentukan. Barulah bisa menggunakan produk pembiayaan ini.

Untuk itu maka penulis merasa perlu untuk mengkaji lebih dalam lagi mengenai: bagaimana mekanisme pemberian produk pembiayaan wisata religi haji di Koperasi Nusantara Cangkol Kota Cirebon? Bagaimana kebijakan yang digunakan dalam pemberian produk pembiayaan wisata religi haji di Koperasi Nusantara Cangkol Kota Cirebon? Kemudian, bagaimana eksistensi produk pembiayaan wisata religi haji ditinjau dari hukum positif dan hukum ekonomi syariah di Koperasi Nusantara Cangkol Kota Cirebon?

\section{LITERATURE REVIEW}

Penelitian tentang pembiayaan wisata religi haji di koperasi bukan satu hal yang baru dilakukan. Meskipun demikian, nampaknya belum ditemukan penelitian yang secara spesifik dikaji dari segi hukum positif dan hukum ekonomi syariah. Berikut beberapa karya yang terdokumentasikan terkait permasalahan yang dikaji, pertama, Nida Farhanah $^{4}$ dalam Jurnal Studi Agama Dan Masyarakat yang berjudul Problematika Waiting List dalam Penyelenggaraan Ibadah Haji Indonesia menyebutkan bahwa konsep awalnya,dana talangan haji tersebut diberikan kepada umat Islam untuk memberikan kemudahan dalam pendaftaran

\footnotetext{
${ }^{4}$ Nida Farhanah, "Problematika Waiting List dalam Penyelenggaraan Ibadah Haji”, Jurnal Studi Agama dan Masyarakat, Vol. 10, No. 1 (Juni, 2016).
}

haji. Tetapi kemudian justru menimbulkan dampak yang cukup pelik yaitu penumpukkan calon jemaah haji dan antrean keberangkatan yang begitu panjang. Berdasarkan hal itu, maka perlu dilakukan kajian untuk mengevaluasi kebijakan tersebut baik menyangkut aspek syar' $i$ yang menjadi landasan hukumnya maupun dampak yang ditimbulkannya demi mewujudkan pemeliharaan terhadap agama (hifz al-dîn) dan mewujudkan kemaslahatan bagi seluruh umat Islam, terutama calon jemaah haji yang berada pada daftar tunggu.

Kedua, Faisal Fani Nasution, Mahmul Siregar, dan Ramli Siregar ${ }^{5}$ dalam Jurnal Hukum Ekonomi yang berjudul Pembiayaan Dana Talangan Haji dalam Perbankan Syariah ditinjau dari UndangUndang Perbankan Syariah mengatakan bahwa pembiayaan talangan haji adalah pinjaman (qardh) dari bank syariah kepada nasabah untuk menutupi kekurangan dana guna memperoleh kursi (seat) haji pada saat pelunasan BPIH (Biaya Perjalanan Ibadah Haji). Dana talangan ini dijamin dengan deposit yang dimiliki nasabah. Nasabah kemudian wajib mengembalikan sejumlah uang yang dipinjam itu dalam jangka waktu tertentu. Atas jasa peminjaman dana talangan ini, bank syariah memperoleh imbalan (fee/ujrah) yang besarnya tak didasarkan pada jumlah dana yang dipinjamkan.

Ketiga, Della Edwinar ${ }^{6}$ dalam Jurnal Ilmiahnya yang berjudul Status Hukum Dana Talangan Haji Bagi Calon Jamaah Haji menyebutkan bahwaperkembangan lembaga keuangan syariah di Indonesia memberikan produk baru yang memfasilitasi setiap muslim di Indonesia

${ }^{5}$ Faisal Fani Nasution, Mahmul Siregar, dan Ramli Siregar, "Pembiayaan Dana Talangan Haji dalam Perbankan Syariah ditinjau dari UndangUndang", Jurnal Hukum Ekonomi, Vol. II, No. 2 (Juni, 2013).

${ }^{6}$ Della Edwinar, "Status Hukum Dana Talangan Haji Bagi Calon Jamaah Haji", Jurnal Ilmiah Program Studi Ilmu Hukum, Vol. 2, No. 2 (Juni, 2015). 
untuk dapat mendaftarkan dirinya berhaji dengan fasilitas dana talangan haji dari lembaga keuangan syariah baik bank maupun non-bank. Berdasar Pasal 1 ayat 4 Peraturan Menteri Agama Nomor 30 Tahun 2013 tentang Bank Penerima Setoran Biaya Penyelenggaraan Ibadah Haji, bahwa Dana Talangan Haji adalah dana yang diberikan sebagai bantuan sementara tanpa mengenakan imbalan oleh Bank Penerima Setoran (BPS) BPIH kepada calon jamaah haji dengan tujuan untuk memberikan kemudahan kepada nasabah/calon nasabah pembiayaan haji untuk mendapatkan porsi haji dengan persyaratan mudah dan proses lebih cepat. Produk dana talangan haji merupakan solusi bagi sebagian muslim yang tidak dapat mencukupi biaya haji secara tunai dengan berdasar prinsip Qard wal Ijarah, yaitu akad pemberian pinjaman dari bank untuk nasabah yang disertai dengan penyerahan tugas agar bank menjaga barang jaminan yang diserahkannya, dalam arti kata, pihak bank menjaga jaminan yang diberikan oleh nasabahnya.

Dari ketiga topik penelitian yang telah dipaparkan di atas, ternyata belum ada tinjauan secara khusus dan komprehensif tentang pembiayaan wisata religi haji pada koperasi dengan menggunakan akad murabahah yang ditinjau dari hukum positif dan hukum ekonomi syariah. Dengan menggunakan tinjauan hukum positif dan hukum ekonomi syariah pada penelitian ini diharapkan akan mengungkapkan bagaimana hukumnya lembaga keuangan non bank yang mengeluar produk pembiayaan yang notabene-nya dikeluarkan oleh koperasi primer namun berakad syariah. Di sinilah letak perbedaan studi ini dengan studi-studi yang telah dilakukan sebelumnya.

\section{METODOLOGI PENELITIAN}

Jenis penelitian yang digunakan adalah penelitian kepustakaan. Penelitian kepustakaan merupakan penelitian yang penemuanya didapatkan dengan mencari data dari berbagai literatur dan referensi yang berhubungan dengan materi pembahasan. $^{7}$ Oleh karena itu, penelitian tentang maqasid syariah tentang obligasi syariah (sukuk) dalam penilitian ini menggunakan metode review dokumen dan trend analysis terhadap penerbitan sukuk di Indonesia dan beberapa manfaat didalamnya.

Metode yang digunakan dalam penelitian ini adalah penelitian kualitatif, yang berusaha menggali, memahami, dan mencari fenomena sosial. Fenomena sosial yang dimaksud adalah motif dan tujuan yang diusung oleh Koperasi Nusantara dalam layanan produk pembiayaan wisata religi haji bagi masyarakat strata sosial menengah ke bawah. Dengan menggunakan metode kualitatif ini dapat menghasilkan data deskriptif berupa kata-kata tertulis atau lisan dari narasumber. Pengumpulan data dilakukan dengan cara observasi dan wawancara secara terbuka.

Dalam penelitian kualitatif ini digunakan teknik pengumpulan data yang meliputi observasi, wawancara mendalam serta kajian literatur. Observasi merupakan pengumpulan data dengan cara mengamati secara langsung objek yang diteliti dilokasi penelitian. Dari penelitian observasi kita dapat melihat secara langsung pola perilaku kesehatan dan juga pola pelayanan kesehatan pada masyarakat, sehingga dengan obeservasi ini peneliti dapat menjaring informasi atau data. ${ }^{8}$ Tidak hanya itu, dalam penelitian inipun menggunakan pendekatan normatif yang dilakukan dengan cara meneliti bahan pustaka yang ada.

Adapun langkah-langkah yang penulis tempuh adalah dengan cara mengumpulkan data untuk memperoleh data yang valid, maka penulis menggunakan studi kasus(case study), yaitu metode yang dilakukan dengan wawancara dilakukan

\footnotetext{
${ }^{7}$ Moh. Nazir, Metode Penelitian (Bandung: Ghalia Indonesia, 2003), 193.

${ }^{8}$ Dedi Aris Kurniawan dan Ali Imron, "Studi Fenomenologi Kegiatan Koperasi Jasa Keuangan Syariah Amanah Ummah", Jurnal Paradigma, Vol. 2 No. 2 (Desember, 2014).
} 
oleh peneliti sendiri, peneliti terjun langsung ke lapangan untuk mencari sejumlah informasi yang dibutuhkan berkenaan dengan pembiayaan wisata religi haji di Koperasi Nusantara.

Teknik pengumpulan data yang digunakan dalam penelitian ini yaitu melalui observasi (pengamatan), interview (wawancara), dan dokumentasi. Ketiga teknik pengumpulan data tersebut diharapkan dapat saling melengkapi, sehingga diperoleh informasi yang diharapkan.

1) Observasi yaitu pengumpulan data yang dilakukan dengan cara melakukan pengamatan dan pencatatan secara sistematis terhadap fenomena-fenomena dan keadaan yang diselidiki. Dalam penelitian ini penulis melakukan observasi dengan cara berkunjung dan mengamati secara langsung aktifitas dan situasi lingkungan kerja di Koperasi Nusantara Cabang Cangkol Kota Cirebon.

2) Wawancara/interview adalah salah satu perangkat metodologi favorit bagi peneliti kualitatif. Wawancara adalah bentuk perbincangan, seni bertanya dan mendengar. Adapun jenis wawancara yang dilakukan oleh peneliti adalah wawancara langsung, dengan bentuk wawancara terstruktur di mana dilakukan dengan cara menyusun beberapa pertanyaan yang dirumuskan dalam pedoman wawancara (terlampir). Wawancara ini digunakan untuk mendapatkan informasi mengenai identitas responden yaitu bagian managemen dan informasi Koperasi Nusantara mengenai sejarah berdirinya, status badan hukumnya, bagaimana perkembangan produknya, minat serta antusias masyarakat akan kehadiran Koperasi Nusantara ini atau yang berkaitan dengan Koperasi Nusantara.

3) Dokumentasi, yaitu suatu metode yang digunakan untuk mencari data dari halhal atau variable yang berupa catatan, transkip, buku, surat kabar, majalah, prasasti, notulen rapat, agenda dan sebagainya.Dalam penelitian ini peneliti melakukan pengumpulan data melalui dokumentasi dari dokumen-dokumen dari Koperasi Nusantara Cabang Cangkol Kota Cirebon, kitab, bukubuku, brosur, internet dan lain-lain, yang berkaitan dengan pembiayaan talangan haji.

Analisis data adalah proses mengorganisasikan dan mengurutkan data kedalam pola, kategori, dan satuan uraian dasar sehingga dapat ditemukan tema dan dapat dirumuskan hipotesis kerja seperti yang disarankan oleh data. ${ }^{9}$ Setelah beberapa data terkumpul dari hasil observasi dan wawancara peneliti mengkaji beberapa sumber lain dari buku serta artikel yang digunakan oleh penulis sebagai landasan untuk memperkuat beberapa pernyataan yang didapatkan dan kemudian peneliti kembangkan sebagai pembahasan dalam penulisan.

Agar dalam proses selanjutnya kita dapat mengetahui apa saja yang telah ditemukan dan di interpretasi di dalam lapangan, maka kita perlu mengetahui kredibilitasnya dengan menggunakan teknik perpanjangan kehadiran peniliti dilapangan, observasi yang diperdalam, triangulasi (sumber, metode, penelitian dan teori) dan pelacakan kesesuaian hasil. Selanjutnya perlu dilakukan pengecekan dapat atau tidaknya ditransfer ke latar lain (transferability), ketergantungan pada konteksnya (dependability) dan dapat tidaknya dikonfirmasikan kepada sumbernya (confirmability). Jadi, yang dimaksud dengan keabsahan data adalah bahwa setiap keadaan harus memenuhi;

(1) mendemonstrasikan nilai yang benar, (2) menyediakan dasar agar hal itu dapat diterapkan, dan (3) memperbolehkan keputusan luar yang dapat dibuat tentang

${ }^{9}$ M. Burhan Bungin, Penelitian Kualitatif (Jakarta: Kencana, 2007), 133-147. 
konsistensi dari prosedurnya dan kenetralan dari temuan dan keputusan-keputusannya. ${ }^{10}$

Berikut beberapa yang dilakukan dalam uji keabsahan data:

1) Perpanjangan Keikutsertaan, keikutsertaan peneliti sangat menentukan dalam pengumpulan data. Keikutsertaan tersebut tidak hanya dilakukan dalam waktu singkat, akan tetapi memerlukan perpanjangan keikutsertaan pada penelitian dilapangan.

2) Ketekunan Pengamatan, yaitu secara konsisten mencari interpretasi dengan berbagai cara dalam kaitan dengan proses analisis yang konstan atau tentative. Mencari suatu usaha yang membatasi berbagai pengaruh dan mencari apa yang dapat diperhitungkan dan apa yang tidak dapat. Hal ini berarti peneliti hendaknya mengadakan pengamatan dengan teliti dan rinci secara berkesinambungan terhadap faktor-faktor yang menonjol. Kemudian ia menelaah secara rinci sampai pada suatu titik sehingga pada pemerikasaan tahap awal tempak salah satu atau seluruh faktor yang ditelaah sudah dipahami dengan cara yang biasa.

3) Triangulasi adalah teknik pemeriksaan keabsahan data yang memanfaatkan sesuatu yang lain. Di luar data itu untuk keperluan pengecekan atau sebagai pembanding terhadap data itu. Teknik triangulasi yang paling banyak digunakan ialah pemeriksaan melalui sember lainnya. Hal itu dapat dicapai dengan jalan; (a) membandingkan data hasil pengamatan dengan data hasil wawancara, (b) membandingkan apa yang dikatakan orang di depan umum dengan apa yang dikatakannya secara pribadi, (c) membandingkan apa yang dikatakan orang-orang tentang situasi penelitian dengan apa yang dikatakannya sepanjang waktu, (d)

\footnotetext{
${ }^{10}$ Lexy J. Moleong, Metode Penelitian
} (Bandung: Remaja Rosdaya, 1995), 320. membandingkan keadaan dan prespektif seseorang dengan berbagai pendapat dan pandangan orang seperti rakyat biasa, orang yang berpendidikan menengah atau tinggi, orang berada, orang pemerintahan dan (e) membandingkan hasil wawancara dengan isi suatu dokumen yang berkaitan. ${ }^{11}$

\section{KONSEP DASAR}

\section{Pembiayaan Wisata Religi Haji}

Pembiayaan wisata religi haji pada Koperasi Nusantara ini merupakan sebuah lembaga keuangan non bank yang mempunyai sistem operasional yang sudah tersusun secara sistematis. Dalam prosedur pembiayaan ini ada prosedur yang harus dipatuhi oleh pengurus maupun anggota koperasi. Koperasi Nusantara ini merupakan koperasi simpan pinjam (KSP). Hal ini didasarkan juga pada putusan No. 228/SISP/Dep.1/VIII/2013 yang dikeluarkan tanggal 16 Agustus 2013 tentang Surat Ijin Usaha Simpan Pinjam Kepada KSP (Koperasi Simpan Pinjam) Nusantara yang berarti bahwa Koperasi Nusantara sudah menyandang Koperasi Simpan Pinjam.

Jenis pembiayaan yang banyak diminati oleh masyarakat ini merupakan produk layanan terbaru dari Koperasi Nusantara yang baru dikeluarkan (1) satu tahun belakang yaitu pada bulan April 2016. Pembiayaan wisata religi ini merupakan bentuk dana talangan haji yang juga merupakan produk berbasis syariah yang diperuntukan bagi masyarakat yang ingin menunaikan ibadah haji namun kekurangan dana awal atau pelunasan untuk pendaftaran.

Pembiayaan adalah membiayai kebutuhan usaha.Adapun pengertian lain pembiayaan adalah penyediaan uang atau tagihan yang dapat dipersamakan dengan itu, berdasarkan persetujuan atau kesepakatan pinjam meminjam antara bank dan atau

\footnotetext{
${ }^{11}$ Lexy J. Moleong, Metode Penelitian, 327-
} 331. 
lembaga keuangan lainnya dengan pihak yang mewajibkan pihak peminjam untuk melunasi utangnya setelah jangka waktu tertentu dengan imbalan bagi hasil. ${ }^{12}$

Wisata religi haji ini merupakan produk pembiayaan yang dikeluarkan oleh Koperasi Nusantara dalam bentuk pembiayaan haji. Pada dasarnya, produk ini mengacu pada dana talangan haji hanya saja dikemas dalam wajah baru.Pengertian atas Wisata Religi Haji ini tidak jauh berbeda dengan dana talangan haji yaitu sebuah produk lembaga keuangan syariah baik bank dan non-bank yang memberikan fasilitas pinjaman dana bagi nasabah yang hendak menunaikan ibadah haji, yang mana bertujuan untuk menutupi kekurangan dana guna memperoleh porsi haji saat pelunasan Biaya Perjalanan Ibadah Haji (BPIH).

Biaya ibadah haji yang tidak sedikit bagi masyarakat dengan tingkat ekonomi menengah ke atas mungkin bukan menjadi hambatan, mereka bisa mendaftar secara langsung kapan saja. Namun, bagi masyarakat dengan tingkat ekonomi menengah ke bawah, perlu banyak pertimbangan untuk bisa melaksanakan ibadah haji. ${ }^{13}$ Salah satu cara yang bisa mereka gunakan adalah dengan menabung sedikit demi sedikit dalam tempo waktu yang cukup lama untuk bisa mendaftar menjadi calon jamaah haji.

Dengan demikian pemerintah mengelurkan produk pembiayaan dana talangan haji di mana dan ini digunakan untuk masyarakat yang ingin menunaikan ibadah haji namun terkendala oleh setoran biaya pendaftran haji. Adanya produk pembiayaan dana talangan haji dapat membantu masyarakat yang ingin melakukan pemberangkatan haji dengan biaya pendaftaran yang dibantu oleh pihak bank maupun non-bank, sehingga dengan mudah masyarakat dapat terdaftar sebagai

\footnotetext{
${ }^{12}$ Veithza Rivai dan Arviyan Arifin, Islamic Banking: Sebuah Teori, Konsep, dan Aplikasi, (Jakarta: Bumi Aksara, 2000), 700.

${ }^{13}$ A. Rahman Ritonga dan Zainuddin, Fiqih Ibadah (Jakarta: Gaya Media Pratama, 2002), 209.
}

calon jemaah haji.Dapat diartikan bahwa wisata religi haji yaitu pembiayaan talangan haji yang merupakan pembiayaan dimana nasabah calon haji diberikan pinjaman talangan untuk memenuhi syarat penyetoran untuk biaya perjalanan ibadah haji dan nasabah akan melunasinya sebelum keberangkatannya ke haji.

\section{Akad Murabahah}

Dalam menjalankan transaksi atau bisnis, satu hal yang sangat penting adalah masalah akad (perjanjian). Akad sebagai salah satu cara untuk memperoleh harta dalam syariat Islam yang banyak digunakan dalam kehidupan sehari-hari. Akad atau perjanjian atau transaksi dapat diartikan sebagai kemitraan yang terbingkai dengan nilai-nilai syariah. Akad jika ditinjau dalam bahasa Arab yaitu العقد (al-'aqd) artinya perikatan, perjanjian, dan pemufakatan. Pertalian ijab (pernyataan melakukan ikatan) dan kabul (pernyataan menerima ikatan), sesuai dengan kehendak syari'at yang berpengaruh pada obyek perikatan. Semua perikatan (transaksi) yang dilakukan oleh dua pihak atau lebih, tidak boleh menyimpang dan harus sejalan dengan kehendak syari'at, tidak boleh ada kesepakatan untuk menipu orang lain, transaksi dengan barang-barang yang diharamkan dan kesepakatan untuk membunuh seseorang. ${ }^{14}$

Dalam istilah fiqh, secara umum akad berarti sesuatu yang menjadi tekad seseorang untuk melaksanakan, baik yang muncul dari satu pihak, seperti wakaf, talak, sumpah, maupun yang muncul dari dua pihak seperti jual beli, sewa, wakalah, dan gadai. Menurut para ulama fiqhm kata akad didefinisikan sebagai hubungan antara ijab dan kabul sesuai dengan kehendak syariat yang menetapkan adanya pengaruh (akad) hukum dalam objek perikatan. Rumusan akad di atas mengindikasikan bahwa

\footnotetext{
${ }^{14}$ M. Ali Hasan, Berbagai Macam Transaksi dalam Islam (Jakarta: PT. Raja Grafindo Persada, 2003), 44.
} 
perjanjian harus merupakan perjanjian kedua belah pihak untuk mengikatkan diri tentang perbuatan yang akan dilakukan dalam suatu hal yang khusus. Akad ini diwujudkan pertama,dalam ijab dan kabul. Kedua, sesuai dengan kehendak syariat. Ketiga, adanya akibat hukum pada objek perikatan. ${ }^{15}$ Secara khusus akad berarti kesetaraan antara ijab (pernyataan penawaran/pemindahan kepemilikan) dan kabul (penyataan penerimaan kepemilikan) dalam ruang lingkup yang disyariatkan dan berpengaruh pada sesuatu. ${ }^{16}$

Murabahah merupakan masdar dari kata rabaha-yurabihu-murabahatan. Secara terminologi, dalam kitab Tuhfah al-Fuqaha disebutkan, jual beli murabahah adalah kepemilikan objek jual beli dengan jual beli seraya memberikan pengganti sejumlah dengan harga awal dan tambahan keuntungan atau laba. ${ }^{17}$ Menurut Veithzal Rivai, jual beli murabahah adalah akad jual beli atas suatu barang dengan harga yang disepakati antara penjual dan pembeli, setelah sebelumnya penjual menyebutkan dengan sebenernya harga perolehan atas barang tersebut dan besarnya keuntungan yang diperoleh. ${ }^{18}$

\section{Syarat dan Rukun Akad Murabahah}

Rukun jual beli murabahah sama halnya dengan jual beli pada umumnya, yaitu adanya pihak penjual, pihak pembeli, barang yang dijual, harga dan akad atau ijab kabul. Sementara syarat jual beli murabahah adalah pertama, syarat yang berkaitan dengan shigat atau akad. Akad harus jelas,

${ }^{15}$ Fathurrahman Djamil, Hukum Perjanjian Syariah (Bandung: PT. Cipta Adiya Bhakti, 2001), 247.

${ }^{16}$ Ascarya, Akad dan Produk Bank Syariah (Jakarta: Rajawali Pers, 2007), 35.

${ }^{17}$ Imam Mustofa, Fiqh Mu'amalah Kontemporer (Jakarta: PT RajaGrafindo Persada, 2016), 65.

${ }^{18}$ Veithzal Rivai dan Andria Permata Rivai, Islamic Financial Management; Teori, Konsep dan Aplikasi Panduan Praktis untuk Lembaga Keuangan, Nasabah, Praktisi dan Mahasiswa (Jakarta: Rajawali Pers, 2008), 145. baik ijab maupun kabul. Dalam akad harus ada kesesuaian antara ijab dan kabul, dan kesinambungan antara keduanya.

Kedua, syarat sah jual beli murabahah yaitu 1) akad jual beli yang pertama harus sah, 2) pembeli harus mengetahui harga awal barang yang menjadi obejk jual beli, 3) barang yang menjadi objek jual beli murabahah merupakan komoditas mitsli atau ada padanannya serta dapat diukur, ditakar, ditimbang atau jelas ukuran, kadar dan jenisnya. Tidak diperbolehkan keuntungan merupakan barang yang sejenis dengan objek jual beli, seperti beras dengan beras, emas dengan emas dan sebagainya4) Jual beli akad yang pertama bukan barter barang dengan barang ribawi yamg tidak boleh ditukar dengan barang sejenis.

Barang ribawi menurut ulama Malikiyah adalah makanan yang dapat memberikan energi, menurut Syafi'iyah adalah semua barang yang dapat dikonsumsi, sementara menurut kalangan Hanafiyah dan Hanbaliyah setiap komoditas ditakar dan atau ditimbang. Kalangan ulama dari empat mazhab ini sepakat bahwa emas dan oerak atau barang lain sejenis merupakan barang ribawi. Dengan demikian barang ribawi tidak dapat diperjualbelikan dengan murabahah, misalnya tukar menukar beras dengan beras atau emas dengan emas di mana jumlah salah satu pihak lebih banyak, baik takaran atau timbangannya maka tidak boleh, dan hal ini bukanlah jual beli murabahah,5) Keuntungan atau laba harus diketahui masing-masing pihak yang bertransaksi, baik penjual maupun pembeli, apabila keuntungan tidak diketahui oleh pembeli, maka tidak dapat dikatakan sebagai jual beli murabahah. ${ }^{19}$

Secara singkat, syarat-syarat jual beli murabahah adalah sebagai berikut 1) Para pihak yang berakad harus cakap hukum dan tidak dalam keadaan terpaksa,2)Barang yang menjadi objek transaksi adalah barang

${ }^{19}$ Imam
Kontemporer, 72. 
halal serta jela sukuran, jenis dan jumlahnya, 3) Harga barang harus dinyatakan secara tranparan dan mekanisme pembiayaan disebutkan dengan jelas, dan 4) Pernyataan serah terima dalam ijab kabul harus dijelaskam secara spesifik pihak-pihak yang terlibat yang berakad. ${ }^{20}$

\section{PEMBAHASAN DAN DISKUSI \\ Mekanisme Pemberian Produk Pembiayaan Wisata Religi Haji}

Koperasi ini bergerak dalam lembaga keuangan bukan bank yang memberikan fasilitas pinjaman kepada anggotanya untuk suatu keperluan. Sama halnya dengan bank dan lembaga resmi lainnya, mekanisme pembiayaan telah diketahui negara dan sudah diatur pula dalam Peraturan Menteri Keuangan No. 84/PMK.012/2006 tentang perusahaan pembiayaan.Produk pembiayaan ini memberikan kemudahan dan kemaslahatan bagi masyarakat yaitu agar dapat menutupi kekurangan dana dalam pelunasan porsi haji. Dari sinilah, masyarakat memulai untuk terdaftar menjadi anggota Koperasi Nusantara agar dapat menggunakan pembiayaan dan mendapatkan nomor porsi haji.

Masyarakat yang ingin mendapatkan produk layanan koperasi ini harus terlebih dahulu terdaftar sebagai Anggota Koperasi Nusantara. Karena Koperasi Nusantara hanya memberikan layanan kepada anggota koperasinya saja.Tata cara pendaftaran anggota Koperasi Nusantara ini tidak jauh berbeda dengan koperasi lain yang berbeda hanya jumlah simpanan pokok dan simpanan wajib setiap koperasi berbedabeda yaitu: 1) merupakan Warga Negara Indonesia, 2) mematuhi semua aturan hukum dan perundangan yang berlaku di Indonesia, 3) mengisi, menandatangani, dan menyerahkan formulir permohonan untuk

\footnotetext{
${ }^{20}$ Veithzal Rivai dan Andria Permata Rivai, Islamic Financial Management; Teori, Konsep dan Aplikasi Panduan Praktis untuk Lembaga Keuangan, Nasabah, Praktisi dan Mahasiswa (Jakarta: Bumi Aksara, 2000), 147.
}

menjadi Anggota Koperasi, 4) melunasi Simpanan Pokok sebesar Rp 50.000 dan Simpanan Wajib sebesar Rp 5.000 perbulan dan 5) melampirkan salinan (KTP/SIM/Paspor,bukti pelunasan pembayaran simpanan pokok dan simpanan wajib bulan berjalan,serta bukti-bukti pendukung lainnya untuk memenuhi persyaratan menjadi anggota koperasi. ${ }^{21}$

Setelah calon anggota koperasi resmi terdaftar di keanggotaan Koperasi Nusantara, barulah anggota dapat mengikuti produk pembiayaan ini. Adapun persyaratan pembiayaan wisata religi haji diantaranya yaitu: 1) Foto Copy KTP, 2) Foto Copy Kartu Keluarga (KK), 3) Foto Copy Buku Nikah/Ijazah/Akta Lahir, 4) Foto Copy Nomor Pokok Wajib Pajak (NPWP), dan 5) Keterangan Gaji/Penghasilan atau Surat Keterangan Usaha.

Dalam pengurusan haji oleh Koperasi Nusantara ini menggunakan pembiayaan dengan akad murabahah dalam penentuan ujrah yang telah ditentukan. Hal ini tentu berbeda dengan Fatwa Dewan Syariah Nasional No. 29/DSNMUI/VI/2002 menjelaskan bahwa dalam pengurusan haji bagi nasabah, LKS dapat memperoleh imbalan jasa (ujrah) dengan menggunakan prinsip al-ijarah sesuai dengan fatwa DSN No. 09/DSNMUI/IV/2000.

Jika meninjau Keputusan Menteri Negara Koperasi Dan Usaha Kecil Dan Menengah No. 91/Kep/M.KUKM/IX/2004 tentang Petunjuk Kegiatan Usaha Koperasi Jasa Keuangan Syariah, piutang murabahah adalah tagihan atas transaksi penjualan barang dengan menyatakan harga perolehan dan keuntungan (margin) yang disepakati pihak penjual (koperasi) dan pembeli (anggota, calon anggota, koperas-koperasi ;ain dan atau anggotanya) dan atas transaksi jual beli tersebut, yang mewajibkan anggota untuk melunasi kewajibannya sesuai jangka

\footnotetext{
${ }^{21}$ Company Profile Koperasi Nusantara, dalam http://konusa.indonetwork.co.id/sejarah. Diakses ada tanggal 17 Juli 2017.
} 
waktu tertentu disertai dengan pembiayaan imbalan berupa marjin keuntungan yang disepakati dimuka sesuai akad. ${ }^{22}$

Dalam praktiknya, pengertian akad murabahah di Koperasi Nusantara ini adalah akad jual beli barang/jasa sebesar harga perolehan ditambah dengan margin keuntungan yang telah disepakati di awal. Berikut skema pembiayaan murabahah dalam pembiayaan wisata religi haji di Koperasi Nusantara:

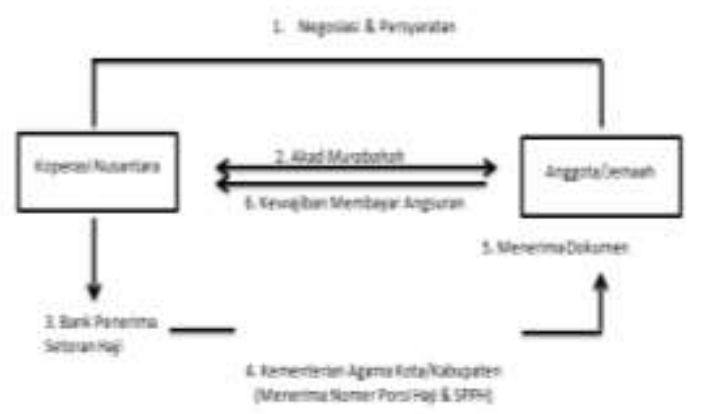

Berdasarkan bagan alur pembiayaanwisata religi haji, berikut peneliti jelaskan bahwa: 1) adanya penawaran negosiasi dan keterangan persyaratan pembiayaan wisata religi haji kepada anggota atau calon jemaah haji, 2) setelah anggota memahami dan menyetujui pembiayaan wisata religi haji ini maka kedua belah pihak (koperasi dan anggota) sudah sepakat dan dapat memulai akad pembiayaan, 3) pihak koperasi menuju Bank Penerima Setoran Haji (BPSH) untuk menyetorkan uang sesuai dengan kesepakatan yang disepakati dalam akad tersebut dan anggota akan menerima Nomor Validasi dari BPSH yang bersangkutan, 4) setelah dari BPSH dan mendapatkan nomor validasi, kedua belah pihak menuju Kementrian Agama (Kemenag) Kota atau Kabupaten sesuai dengan domisili anggota yang bersangkutan untuk mendapatkan Nomor Porsi Haji dan Surat Pendaftaran Pergi Haji (SPPH), 5) anggota atau calon

\footnotetext{
${ }^{22}$ Keputusan Menteri Negara Koperasi dan Usaha Kecil dan Menengah Republik Indonesia Nomor: 91/Kep/M.KUKM/IX/2004 tentang Petunjuk Pelaksanaan Kegiatan Usaha Koperasi Jasa Keuangan Syariah, BAB I Pasal 1 ayat 11, 3.
}

jamaah haji menerima dua dokumen tersebut yaitu Nomor Porsi Haji dan SPPH, 6) anggota wajib membayar angusran sesuai dengan kesepakatan pada saat akad dilakukan.

Di dalam pembiayaan wisata religi haji ada barang yang harus dijaminkan, yaitu berupa nomor porsi haji dari Kemenag dan SPPH (Surat Pendaftaran Pergi Haji) Artinya setelah semua proses transaksi selesai dilakukan, nomor porsi haji dan SPPH akan diambil oleh pihak koperasi sebagai jaminan demi keberlangsungannya kewajiban anggota membayar angsuran.

Sebagaimana Fatwa MUI No. 74/DSN-MUI/I/2009 tentang penjaminan syariah dijelaskan bahwa penjaminan syariah yang dilakukan atas dasar prinsip syariah itu diperbolehkan. Artinya adanya jaminan pada pembiayaan ini adalah diperbolehkan. Disamping itu unsur yang terkandung dalam pembiayaan inipun adalah sah secara syariah atau tidak menyimpang. Selain itu dalam Peraturan Menteri Koperasi Dan Usaha Menengah Kecil No. 16/Per/M.KUKM/IX/2015 tentang pelaksaan kegiatan usaha simpan pinjam dan pembiayaan syariah oleh koperasi pasal 28 ayat 3 dijelaskan bahwa koperasi dapat menetapkan jaminan atas pinjaman atau pembiayaan yang dapat berupa barang atau hak tagih yang diperhitungkan senilai dana pinjaman atau pembiayaan yang bersangkutan. Hal ini yang menjadi dasar adanya jaminan di Koperasi Nusantara. Sebagaimana yang terjadi dalam pembiayaan wisata religi haji ini. Pembiayaan ini menggunakan jaminan dalam bentuk nomor porsi haji dan SPPH yang akan dijadikan sebagai jaminan apabila anggota tidak dapat memenuhi kewajibannya dalam tempo yang sudah ditentukan.

Peneliti menilai adanya jaminan dalam murabahah yang dilakuakan pihak koperasi diperbolehkan. Hal ini untuk menekan anggota yang melakukan pembiayaan agar terpenuhi kewajibannya. Sebagaimana dijelaskan dalam Fatwa 
Nomor 04/DSN-MUI/IV/2000 bahwa jaminan dalam murabahah diperbolehkan agar serius dalam pesanannya. Setelah semua proses dilakukan, anggota koperasi yang mengajukan pembiayaan ini harus sadar akan kewajibannya membayar angsuran perbulannya hingga tempo waktu yang sudah disepakati bersama.

\section{Kebijakan Koperasi Nusantara Dalam Penanganan Pembiayaan Wisata Religi Haji Yang Bermasalah}

Setiap lembaga keuangan bank maupun non-bank tentu mempunyai kebijakan masing-masing dalam mekanisme pembiayaannya. Tidak menutup kemungkinan sering terjadi permasalahan dalam pembiayaan yaitu pembiayaan yang dalam pelaksanaanya belum mencapai atau memenuhi target yang ditentukan oleh suatu lembaga, di mana anggota mengalami kesulitan dalam penyelesaian kewajibankewajibannya.

Dalam pemberian pembiayaan, selisih merugikan mungkin terjadi jika pelaksanaan tidak sesuai dengan rencana yang ditetapkan. Selisih ini dapat berupa angsuran yang tidak sesuai dengan perjanjian diawal, nasabah tidak dapat melunasi pinjamannya dalam jangka waktu yang telah disepakati bersama, dan pembiayaan sebelumnya. Kondisi seperti inilah yang biasanya disebut dengan pembiayaan bermasalah. Masalah merupakan suatu kondisi yang mempunyai potensi untuk menimbulkan kerugian atau keuntungan yang luar biasa. Masalah terjadi jika terdapat selisih antara rencana dan realisasi, dapat berupa selisih merugikan atau menguntungkan.

Koperasi Nusantara sebagai lembaga keuangan non-bank yang bergelut di pembiayaan dan mempunyai perkembangan yang pesat tidak terlepas dari berbagai permasalahan, salah satunya adalah mengenai pembiayaan yang macet. Pembiayaan yang terjadi di Koperasi Nusantara ini terjadi karena berbagai faktor, diantaranya yaitu: $\left.{ }^{23} 1\right)$ usaha anggota mengalami kebangkrutan (biasanya dialami oleh pedagang),2) terjadinya gagal panen oleh anggota yang berprofesi sebagai petani sehingga tidak dapat membayar angsuran,3) adanya kasus perkara yang melibatkan anggota, sehingga pembiayaan tidak dapat dilanjutkan. Ketiga faktor di atas jelas mempengaruhi kelancaran dalam angsuran pembiayaan yang ada di Koperasi Nusantara. Ketika usaha yang dilakukan oleh para anggotanya mengalami permasalahan, maka akan berdampak pula pada pendapatan yang dihasilkan oleh anggota.

Dalam prakteknya peraturan mengenai pembiayaan bermasalah ini dijelaskan dalam Badan Pengawas Pasar Modal dan Lembaga Keuangan (BAPEPAM) No. PER-04/BL/2007 tentang Akad-akad Yang Digunakan Dalam Kegiatan Perusahaan Pembiayaan Berdasarkan Prinsip Syariah pasal 32-33. Dijelaskan bahwa, apabila konsumen telah dinyatakan pailit dan gagal menyelesaikan hutang dalam murabahah, maka Perusahaan Pembiayaan wajib menunda tagihan hutang sampai dengan konsumen ia menjadi sanggup kembali membayar tagihan hutang atau adanya penyelesaian berdasarkan kesepakatan bersama. Serta apabila konsumen mampu membayar namu menunda-nunda maka sanksi dapat berupa denda sosial (ta'zir ) ataupun ganti rugi (ta`widh) berdasarkan atas sebab tertundanya pembayaran dan akibat yang ditimbulkan dari penundaan tersebut.

Pada penanganan kasus pembiayaan bermasalah ini, ketika semua proses sudah dilakukan namun tak kunjung ada i'tikad baik dari pihak yang bermasalah maka jalan terakhir yang Koperasi Nusantara tempuh adalah penyitaan jaminan. Penyitaan jaminan ini merupakan cara terakhir apabila anggota atau calon jamaah haji benar-benar

\footnotetext{
${ }^{23}$ Hasil wawancara dengan bapak Kasmir selaku Account Officer Koperasi Nusantara Cabang Cirebon pada hari Kamis, 24 Agustus 2017.
} 
tidak mempunyai i'tikad baik untuk melunasi semua hutang-hutangnya. ${ }^{24}$ Dalam hal ini Koperasi Nusantara sudah membuat kebijakan yang baik dan sesuai dengan aturan yang berlaku. Kebijakan inipun tidak hanya berlaku untuk produk pembiayaan wisata religi haji saja, namun berlaku untuk semua jenis pembiayaan yang ada di Koperasi Nusantara. Tindakan penyitaan jaminan dilakukan ketika pihak peminjam tidak ada i'tikad baik.

\section{Analisis Produk Pembiayaan Wisata Religi Haji Ditinjau Dari Hukum Positif Dan Hukum Ekonomi Syariah}

Pembiayaan wisata religi haji pada Koperasi Nusantara ini merupakan sebuah lembaga keuangan non bank yang mempunyai sistem operasional yang sudah tersusun secara sistematis. Dalam prosedur pembiayaan ini ada prosedur yang harus dipatuhi oleh pengurus maupun anggota koperasi. Koperasi Nusantara ini merupakan koperasi simpan pinjam (KSP). Hal ini didasarkan juga pada putusan No. 228/SISP/Dep.1/VIII/2013 yang dikeluarkan tanggal 16 Agustus 2013 tentang Surat Ijin Usaha Simpan Pinjam Kepada KSP (Koperasi Simpan Pinjam) Nusantara yang berarti bahwa Koperasi Nusantara sudah menyandang Koperasi Simpan Pinjam.

Berikut adalah dasar hukum atas diadakannya pembiayaan wisata religi haji di Koperasi Nusantara, yaitu pertama, Peraturan Menteri Agama (PMA) No. 30 Tahun 2013 tentang Bank Penerima Setoran Biaya Penyelenggaran Ibadah Haji, dalam PMA ini diterangkan pada pasal 1 ayat 4 (empat) bahwa dana talangan haji adalah dana yang diberikan sebagai bantuan sementara tanpa mengenakan imbalan oleh BPS BPIH kepada calon jemaah haji. Sementara yang dilakukan oleh Koperasi Nusantara ini adalah BPS BPIH bertindak sebagai pihak ketiga (stakeholder). Jadi, dana pinjaman yang ditawarkan oleh

\footnotetext{
${ }^{24}$ Kasmir, Manajemen Perbankan (Jakarta: Raja Grafindo Persada, 2000), 73.
}

koperasi ini nantinya disalurkan langsung kepada BPS BPIH.Kedua, Undang-Undang (UU) No. 25 Tahun 1992 tentang Perkoperasian, dalam pasal 44 UU No. 25 Tahun 1992 tentang perkoperasian menerangkan koperasi dapat menghimpun dana dan menyalurkan melalui kegiatan usaha simpan pinjam dari dan untuk anggota koperasi yang bersangkutan. Kegiatan usaha koperasi ini dapat dilakukan sebagai salah satu atau satu-satunya kegiatan usaha koperasi.Ketiga,Peraturan Pemerintah (PP) No. 9 Tahun 1995 tentang Pelaksanaan Kegiatan Usaha Simpan Pinjam Oleh Koperasi, pada pasal 1 (satu) ayat 3 (tiga) menyebutkan bahwa unit simpan pinjam adalah unit koperasi yang bergerak pada bidang usaha simpan pinjam, sebagian bagian dari kegiatan usaha koperasi yang bersangkutan.Keempat, Peraturan Otoritas Jasa Keuangan No. 29/POJK.05/2014 tentang Penyelenggaraan Usaha Perusahaan Pembiayaan, pada Bab II pasal 2 (dua) ayat 1 (satu) dijelaskan bahwa kegiatan usaha perusahaan pembiayaan meliputi; a) pembiayaan investasi, b) pembiayaan modal, c) pembiayaan multiguna, d) kegiatan usaha pembiayaan berdasarkan persetujuan OJK. Kemudian pada ayat 2 (dua) dijelaskan juga bahwa selain kegiatan usaha sebagaimana dijelasan diatas, perusahaan pembiayaan dapat melakukan sewa operasi (operating lease) dan atau kegiatan berbasis fee sepanjang tidak bertentangan dengan perpu disektor jasa keuangan OJK. Sebagaimana yang dimaksud dalam POJK ini pembiayaan wisata religi haji ini termasuk pembiayaan dengan persetujuan OJK. Kelima,Badan Pengawas Pasar Modal dan Lembaga Keuangan (BAPEPAM) No. PER04/BL/2007 tentang Akad-akad Yang Digunakan Dalam Kegiatan Perusahaan Pembiayaan Berdasarkan Prinsip Syariah, pada pembiayaan wisata religi haji ini, menggunakan pembiayaan syariah dengan menggunakan akad murabahah sebagaimana yang terdapat pada pasal 1 (satu) ayat 5 (lima) adalah akad pembiayaan 
untuk pengadaan suatu barang dengan menegaskan harga belinya (harga perolehan) kepada pembeli dan pembeli membayarnya secara angsuran dengan harga lebih sebagai laba. Objek murabahah ini sendiri haruslah memenuhi ketentuan seperti dapat dinilai dengan uang, dapat diterima oleh konsumen, tidak dilarang oleh syariah Islam dan spesifikasinya harus dinyatakan dengan jelas. Pembiayaan wisata religi haji ini merupakan persamaan dari dana talangan haji. Artinya objek pembiayaan ini dapat dinilai dengan uang dan dapat diterima oleh konsumen dalam bentuk nomor porsi haji.

Namun di sisi lain Menteri Agama mengeluarkan Peraturan Menteri Agama (PMA) No. 24 Tahun 2016 tentang Perubahan Atas Peraturan Menteri Agama No. 30 Tahun 2013 tentang Bank Penerima Setoran Biaya Penyelenggaraan Ibadah Haji pada pasal 6A, "BPS BPIH dilarang memberikan layanan dana talangan haji baik secara langsung maupun tidak langsung" yang kemudia diperjelas dalam pasal 12A ayat 1 (satu) bahwa dana talangan haji yang telah diberikan oleh BPS BPIH sebelum diberlakukannya Peraturan Menteri ini, harus diselesaikan oleh BPS BPIH dengan jemaah haji, ayat 2 (dua) penyelesaian sebagaimana disebutkan dalam ayat 1 (satu) paling lambat tanggal 31 Desember 2020 terhitung sejak dikeluarkannya pengundangan Peraturan Menteri ini.

Dengan hal ini jika ditinjau dari hukum positif maka pembiayaan wisata religi haji yang dilakukan oleh Koperasi Nusantara ini adalah ilegal. Karena Pemerintah sudah mencabut izin penggunaan dana talangan haji dalam bentuk apapun. Sedangkan Koperasi Nusantara dengan beraninya mengeluarkan produk inovasi yang merupakan dana talangan haji yang dikemas dengan warna dan kata yang beda.

Hukum Ekonomi Syariah adalah suatu cabang ilmu pengetahuan yang berupaya untuk memandang, menganalisis dan akhirnya menyelesaikan permasalahanpermasalah ekonomi dengan cara-cara
Islam, yaitu berdasarkan Al- Qur'an dan Sunnah Nabi. Dalam praktiknya ekonomi syariah ini berpacu kepada Kompilasi Hukum Ekonomi Syariah (KHES) bukan lagi berpacu pada Kompilasi Hukum Islam (KHI). Hal ini disebabkan adanya surat edaran nomor 8 tahun 2008 tentang eksekusi putusan Badan Arbitrase Syariah oleh Ketua Mahkamah Agung RI, terkait pemberian petunjuk pada kegiatan usaha yang dilaksanakan menurut prinsip syariah.

Dengan demikian, apabila pembiayaan wisata religi haji dilihat dari sisi pembiayaannya, maka hal ini tentu diperbolehkan. Sebagaimana firman Allah dalam QS. Al-Maidah berikut:

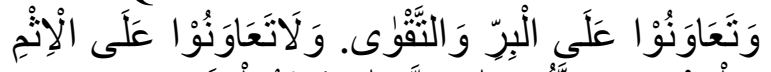

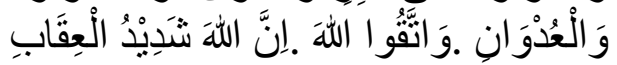

Artinya: Dan tolong-menolonglah kamu dalam (mengerjakan) kebajikan dan takwa, dan jangan tolong-menolong dalam berbuat dosa dan pelanggaran. dan bertakwalah kamu kepada Allah, Sesungguhnya Allah Amat berat siksa-Nya. ${ }^{25}$

Dari ayat di atas dapat ditafsirkan bahwa sesungguhnya tolong menolong dalam mengerjakan kebaikan adalah perbuatan yang terpuji. Sebagaimana dengan prinsip Koperasi Nusantara melalui pembiayaan wisata religi haji ini merupakan sebuah inovasi baru yang dapat membantu sesama memudahkan masyarakat dalam menyempurnakan dan menunaikan rukun Islam yang ke lima yaitu Haji.

Sedangkan Sunnah menurut istilah adalah segala sesuatu yang bersumber dari Nabi SAW dalam bentuk ucapan, perbuatan dan penetapan yang baik untuk menjadi dalil bagi hukum syar'i.Dalam pembahasan di atas, yang hal sama mengenai dalam pembiayaan diungkapkan Rasulullah SAW dalam Hadits Nabi riwayat Ibnu Majah No. 2176 yaitu:

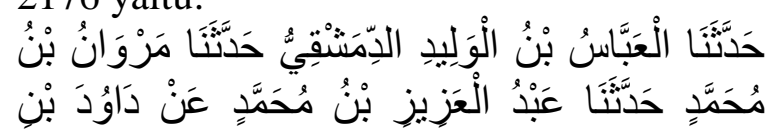

${ }^{25}$ QS. Al-Maidah (5): 2. 


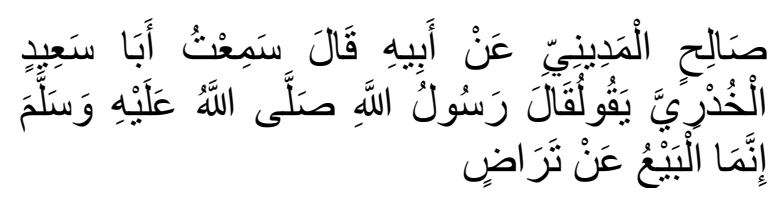

"Telah menceritakan kepada kami Al Abbas bin Al Walid Ad Dimasyqi berkata, telah menceritakan kepada kami Marwan bin Muhammad berkata, telah menceritakan kepada kami Abdul Aziz bin Muhammad dari Dawud bin Shalih Al Madini dari Bapaknya berkata; aku mendengar Abu Sa'id ia berkata, "Rasulullah shallallahu 'alaihi wasallam bersabda: "Hanyasanya jual beli berlaku dengan saling ridla."

Menurut peneliti maksud sabda Rasulullah SAW di atas adalah barang siapa yang melakukan transaksi jual beli maka haruslah bersikap saling ridha. Artinya dalam pembiayaan wisata religi haji ini, antara kedua belah pihak harus saling ridha. Penjual yang di sini adalah koperasi harus memaparkan apa yang harusnya dipaparkan. Dan anggota sebagai pembeli harus dapat memahami yang sudah dipaparkan dan memenuhi apa yang diperjanjikan. Dengan demikian, akan ada rasa saling ridha di dalam perjanjian pembiayaan antara pihak koperasi dengan anggota pembiayaan.

Dalam kaidah fiqh terdapat kaidah yang artinya; "segala sesuatu tergantung pada tujuannya". Pengertian kaidah ini adalah bahwa hukum yang berimplikasi terhadap suatu perkara yang timbul dari perbuatan atau perkataan subjek hukum (mukallaf) tergantung pada maksud dan tujuan dari perkara tersebut. ${ }^{26}$

Jadi dalam praktek pembiayaan wisata religi haji ini, ketika maksud dari pihak koperasi dalam menawarkan produk adalah untuk membantu atau saling tolongmenolong dalam kebaikan dalam hal ini adalah membantu anggota untuk dapat menunaikan ibadah haji, maka hukumnya adalah dibolehkan. Namun ketika dalam penawaran ini mempunyai maksud tidak baik seperti menipu atau mengelabuhi

\footnotetext{
Fiqhiyyah, 6.
}

anggota pembiayaan maka hukumnya menjadi haram.

Dalam prakteknya pihak koperasi menawarkan pembiayaan yang akan dilakukan oleh anggota atau calon jamaah haji ini, apakah akan menggunakan biaya penuh dari koperasi ataukah hanya sebagian. Kemudian pihak koperasi pun akan mejelaskan bagaimana rincian biaya yang digunakan selama proses pendaftaran calon jamaah haji. Nama yang digunakan dalam transaksi inipun menggunakan nama anggota atau calon jamaah haji.

Dalam Fatwa MUI No. 29/DSNMUI/VI/2000 tentang Pembiayaan Pengurusan Ibadah Haji Lembaga Keuangan Syariah (LKS) akad yang digunakan dalam pembiayaan ini adalah ijarah bukan murabahah. Dengan hal ini, pembiayaan wisata religi haji ini merupakan produk yang tidak halal ditinjau dari hukum ekonomi syariahnya. Karena apa yang di jabarkan dalam peraturan-peraturan yang berlaku tidak diindahkan oleh pihak koperasi walaupun memang produk pembiayaan ini mempunyai manfaat tersendiri bagi masyarakat luas.Bukan hanya itu dalam Al-Qur'an pun dijelaskan bahwa memakan harta orang lain dengan jalan yang bathil adalah perbuatan yang tidak perpuji.

Koperasi Nusantara Kota Cirebon ini merupakan jenis koperasi primer namun di dalam produknya terdapat produk dengan prinsip syariah. Tentu hal ini merupakan hal yang tidak sepatutnya dilakukan oleh koperasi lainnya kecuali jika koperasi tersebut mempunyai unit syariah seperti Koperasi Simpan Pinjam (Kospin) Jasa Syariah. Selain itu, Koperasi Nusantara ini mengeluarkan produk simpan pinjam yang dikemas dengan nama pembiayaan wisata religi haji yang berprinsip syariah serta menggunakan akad murabahah.

Dalam praktek pembiayaan wisata religi haji ini pihak Koperasi Nusantara menggunakan prinsip syariah dengan akad murabahah. Hal ini bertentangan dengan Fatwa MUI No. 29/DSN-MUI/VI/2000 
tentang Pembiayaan Pengurusan Ibadah Haji Lembaga Keuangan Syariah (LKS) akad yang digunakan dalam pembiayaan ini adalah ijarah. Bukan hanya itu, dalam fatwa ini juga dipersyaratkan bahwa jasa pengurusan haji yang dilakukan tidak boleh dengan pemberian talangan haji.

Melihat (PMA) No. 24 Tahun 2016 tentang Perubahan Atas Peraturan Menteri Agama No. 30 Tahun 2013 tentang Bank Penerima Setoran Biaya Penyelenggaraan Ibadah Haji dapat diketahui bersama bahwa dana talangan haji atau pembiayaan sejenisnya sudah dilarang. Namun dalam prakteknya Koperasi Nusantara masih menawarkan produk pembiayaan ini.

\section{KESIMPULAN}

Berdasarkan hasil penelitian yang dilakukan, dapat disimpulkan 3 (tiga) macamkesimpulan, yaitu pertama, mekanisme pembiayaan wisata religi haji yang diterapkan oleh Koperasi Nusantara ini dimulai dari calon anggota pembiayaan mendaftar terlebih dahulu menjadi anggota Koperasi Nusantara. Setelah mendaftar, baru kemudian anggota bisa mengajukan pembiayaan wisata religi haji dengan menyerahkan beberapa persyaratan seperti foto copy KTP, Kartu Keluarga, Buku Nikah/Ijazah/Akta Lahir, Nomor Pokok Wajib Pajak, dan Keterangan Gaji/Surat Keterangan Usaha. Apabila syarat yang dibutuhkan memenuhi kriteria maka proses selanjutnya adalah pengajuan ke Koperasi Nusantara Pusat. Kemudian pencairan dana akan dilakukan langsung melalui Bank Penerima Setoran Haji. Jadi tidak diberikan secara cash kepada anggota melainkan langsung droping dana melalui tabungan anggota.

Kedua, dalam pemberian pembiayaan, pihak koperasi pasti sudah membuat kebijakan dalam pemberian pembiayaan wisata religi haji. Sementaraitu, apabila anggota dalam perjalanannya membayar angsuran mengalami macet atau bermasalah maka pihak koperasi akan melakukan pemberian surat teguran, apabila selama 2 bulan berturut-turut anggota tidak membayaran angsuran. Kemudian apabila surat teguran tidak dipindahkan maka pihak koperasi akan mendatangi rumah anggota dibulan ke 3, dan jikaanggota tetap menunggak hingga 6 bulan berturut-turut maka pihak koperasi akan melakukan tindakan pembatalan pembiayaan. Hal ini berlaku apabila anggota yang bermasalah terlibat dalam perkara hukum baik pidana maupun perdata.

Ketiga, Koperasi Nusantara sebagai koperasi simpan pinjam (KSP) yang menghadirkan produk pembiayaan wisata religi haji cukup menarik perhatian masyarakat luas. Dalam prakteknya, pembiayaan ini bertolak belakang dengan (PMA) No. 24 Tahun 2016 tentang Perubahan Atas Peraturan Menteri Agama No. 30 Tahun 2013 tentang Bank Penerima Setoran Biaya Penyelenggaraan Ibadah Haji bahwa pembiayaan dengan jenis talangan haji telah dilarang. Serta prinsip syariah yang digunakan dalam pembiayaan ini berlawanan dengan Fatwa MUI No. 29/MUI-DSN/VI/2000. 


\section{DAFTAR PUSTAKA}

Ascarya. Akad dan Produk Bank Syariah. Jakarta: Rajawali Pers, 2007.

Bungin, M. Burhan. Penelitian Kualitatif. Jakarta: Kencana, 2007.

Company Profile Koperasi Nusantara, dalam

http://konusa.indonetwork.co.id/sejar ah. Diakses ada tanggal 17 Juli 2017.

Djamil, Fathurrahman. Hukum Perjanjian Syariah. Bandung: PT. Cipta Adiya Bhakti, 2001.

DSN-MUI. Himpunan Fatwa Dewan Syari'ah Nasional, Cet. 3. Jakarta: CV. Gaung Persada, 2006.

Edwinar, Della. "Status Hukum Dana Talangan Haji Bagi Calon Jamaah Haji”, Jurnal Ilmiah Program Studi Ilmu Hukum, Vol. 2, No. 2 (Juni, 2015).

Farhanah, Nida. "Problematika Waiting List dalam Penyelenggaraan Ibadah Haji”, Jurnal Studi Agama dan Masyarakat, Vol. 10, No. 1 (Juni, 2016).

Hasan, M. Ali Hasan, Berbagai Macam Transaksi dalam Islam (Jakarta: PT. Raja Grafindo Persada, 2003.

Kasmir. Manajemen Perbankan. Jakarta: Raja Grafindo Persada, 2000.

Keputusan Menteri Negara Koperasi dan Usaha Kecil dan Menengah Republik Indonesia Nomor: 91/Kep/M.KUKM/IX/2004 tentang Petunjuk Pelaksanaan Kegiatan Usaha Koperasi Jasa Keuangan Syariah.

Kurniawan, Dedi Aris Kurniawan dan Ali Imron, "Studi Fenomenologi Kegiatan Koperasi Jasa Keuangan Syariah Amanah Ummah", Jurnal Paradigma, Vol. 2 No. 2 (Desember, 2014).

Moleong, Lexy J. Metode Penelitian. Bandung: Remaja Rosdaya, 1995.

Mustofa, Imam. Fiqh Mu'amalah Kontemporer. Jakarta: PT. RajaGrafindo Persada, 2016.
Nasution, Faisal Fani, Mahmul Siregar, dan Ramli Siregar, "Pembiayaan Dana Talangan Haji dalam Perbankan Syariah ditinjau dari UndangUndang", Jurnal Hukum Ekonomi, Vol. II, No. 2 (Juni, 2013).

Nazir, Moh. Metode Penelitian. Bandung: Ghalia Indonesia, 2003.

Nurhayati, Fitri Nurhayati dan Ika Saniyati Rahmaniyah. Koperasi Syariah. Surakarta: PT Era Intermedia, 2008.

Pahlevi, Tommy Jorghi. "Tinjauan Yuridis terhadap Penggunaan Dana Talangan Haji Menurut Hukum Islam Dikaitkan dengan Undang-Undang Nomor 34 Tahun 2009 tentang Penyelenggaraan Haji dan UndangUndang Nomor 21 Tahun 2008 tentang Perbankan Syariah", Skripsi. Bandung: Universitas Pasundan Bandung, 2011.

Rifai, Muhammad Bahtiyar. "Tinjauan Hukum Islam terhadap Produk Dana Talangan Haji”, Skripsi. Yogyakarta: UIN Sunan Kalijaga, 2010.

Ritonga, A. Rahman dan Zainuddin. Fiqih Ibadah. Jakarta: Gaya Media Pratama, 2002.

Rivai, Veithza dan Arviyan Arifin. Islamic Banking: Sebuah Teori, Konsep, dan Aplikasi. Jakarta: Bumi Aksara, 2000.

Rivai, Veithzal dan Andria Permata Rivai. Islamic Financial Management; Teori, Konsep dan Aplikasi Panduan Praktis untuk Lembaga Keuangan, Nasabah, Praktisi dan Mahasiswa. Jakarta: Rajawali Pers, 2008.

Sarwat, Ahmad. Seri Fiqh Kehidupanv (6) Haji \& Umrah. Jakarta: Publishing, 2011. 